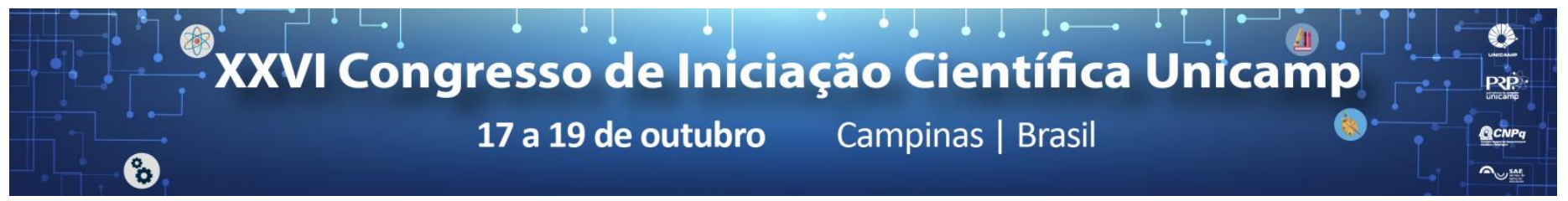

\title{
Análise Comparativa entre os Modelos de Gestão da Liga Norte-americana de Futebol e Campeonato Brasileiro de Futebol.
}

\section{Pedro Antonio S. Broglio*, Leandro Carlos Mazzei.}

\section{Resumo}

As ligas norte-americanas são empresas franqueadoras que tem como função primordial criar e garantir o cumprimento de regras e normas que mantem o equilíbrio competitivo entre as franquias. Essas funções presam principalmente por manter a atração dos fãs pelos atletas, jogos e campeonatos, e por consequência conservar a lucratividade das franquias. As ligas norte-americanas são referências quando o assunto é gestão esportiva e este projeto tem como principal colocação analisar o modelo de administração regido por uma liga esportiva americana nova, a Major League Soccer, e compará-la com o Campeonato Brasileiro de Futebol da Série A.

\section{Palavras-chave:}

Liga, Gestão, Futebol.

\section{Introdução}

A Major League Soccer (MLS), principal liga norte-americana de futebol masculino, foi fundada em 1996 respondendo uma determinação da FIFA. Após seus anos inicias passarem por períodos conturbados, a liga atualmente mostra um alto crescimento dentre os grandes campeonatos do mundo quando o assunto é a média de público.

Os números levam a crer que o sucesso esportivo e econômico da liga norte-americana é desfecho de um modelo de gestão orientado para negócios e entretenimento, profissionalizado em todos os seus níveis, envolvendo os jogadores e determinados parâmetros que regulam suas atuações (MATTAR, 2014).

O objetivo desse estudo é analisar com maior detalhamento as diferenças entre a gestão da MLS e do Campeonato Brasileiro e projetar atividades responsáveis por elevar a média de público da MLS, além de apontar se elas, caso inseridas no modelo brasileiro, seriam aptas a alavancar a média de público no campeonato brasileiro.

\section{Resultados e Discussão}

A metodologia primordial utilizada para alcançar a meta desse trabalho é a pesquisa bibliográfica e documental, a qual, primeiro existem estudos sistematizados e desenvolvidos e segundo, a partir de informações existentes em documentos oficiais do objeto a ser estudado.

O estudo, em primeiro momento, delimitou a média de público dos campeonatos entre os anos de 2014 e 2017, chegando à conclusão que mesmo sem o apelo cultural pelo futebol nos Estados Unidos a média de público da liga norte americana (21.125) supera os números atingidos pelo Campeonato Brasileiro (17.069), no mesmo período (TRANFERMARKET.COM.BR).

Por segundo, foram realizadas análises e comparações entre os sites dos campeonatos, onde se observou diferenças quando o assunto é consumidor. $O$ site norte-americano usa estratégias que priorizam o seu espectador, enquanto 0 site brasileiro apresenta ferramentas burocráticas, priorizando os clubes.
Por fim, as análises nos documentos oficiais dos campeonatos e seus mantenedores afirmaram que a estratégia da liga norte-americana é voltada principalmente para o mercado externo e preza o equilíbrio competitivo entre as franquias, ao passo que o sistema brasileiro é voltado para os interesses que não visam o desenvolvimento do campeonato ou do esporte, além da falta de "profissionalização" dos gestores que atuam no futebol nacional.

\section{Conclusões}

A explicação desses dados pode ser identificada, dentre outros fatores, nas características que diferenciam o sistema atualmente existente no Brasil com relação ao formato do evento, além das ausências de políticas, estrutura, sistema e visão de seus responsáveis. Dentre outras diversas características e diferenças, fica claro que o modelo de Liga Esportiva nos Estados Unidos é diferente do modelo de campeonato existente no Brasil.

Portanto, confirma-se que o sistema norteamericano é responsável pelo crescimento da Major League Soccer e que algumas ferramentas são fundamentais para tal acontecimento, podendo algumas, se usadas corretamente, influenciar positivamente no aumento do público nos estádios brasileiros.

\section{Agradecimentos}

Presto agradecimento ao meu orientador Prof. Dr. Leandro Carlos Mazzei e as instituições que ajudaram com a pesquisa: FCA-UNIMCAP e CNPQ.

\footnotetext{
Mattar, M. F. Na trave: o que falta para o futebol brasileiro ter uma gestão profissional. Rio de Janeiro: Elsevier Campus, 2014.

Transfermarkt Gmbh \& Co. Kg. Transfermarkt football - Clubes - Número de espectadores. Disponível em <https://www.transfermarkt.com.br/> Acessado em 12 de abril de 2018.
} 